\title{
'n Nuwe boek met nuwe perspektief op die preekvoorbereidingsproses
}

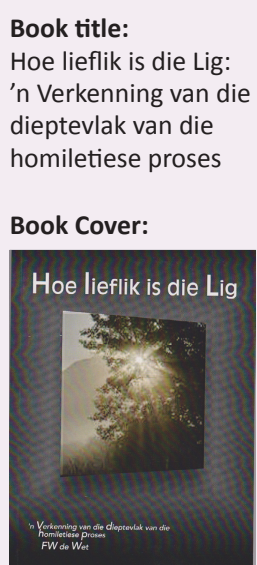

Author:

F.W. de Wet

ISBN:

978-0-86955-194-3

Publisher:

Potchefstroom Theological

Publications, 2011, R150.00

*Book price at time of review

\section{-}

Review title:

'n Nuwe boek met nuwe perspektief op die

preekvoorbereidingsproses

Reviewer:

Hennie J.C. Pieterse ${ }^{1}$

\section{Affiliation:}

${ }^{1}$ Departement of Philosophy, Practical and Symantical

Theology, University of South

Africa, South Africa

Email:

pietehjc@absamail.co.za

Postal address:

Marais Street 262, Brooklyn

0181, South Africa

How to cite this book review: Pieterse, H.J.C., 2013,

"n Nuwe boek met nuwe perspektief op die preekvoorbereidingsproses', In die Skriflig/In Luce Verbi 47(1), Art. \#129, 1 page. http://dx.doi.org/10.4102/ ids.v47i1.129

\section{Read online:}

Scan this QR
code with your
smart phone or
mobile device
to read online.

In die laaste vyf dekades het verskuiwende ontwikkelings in die wêreld waarin ons leef, plaasgevind en gevolglik ook in die benaderings tot die prediking. Hierdie verskuiwings in die studie van die Homiletiek kan in breë trekke soos volg gestel word: vanaf die teks na die hoorder, vanaf eksegese na hermeneutiek en vanaf Christologie na Pneumatologie in die homiletiese teorievorming. Soms handhaaf sommige predikers nog 'n bipolêre balans tussen die aspekte wat in die Homiletiek eietyds ter sprake kom, maar meestal word in eensydighede verval. Prof. De Wet se navorsingsvraag is tereg of die verkenning van die dieptevlak van die ruimte waarin die homiletiese proses voltrek word, daartoe kan bydra dat daar nie op 'n eendimensionele, eensydige, rigiede en onverantwoordelike manier met die teks en die gemeente omgegaan word nie. Op 'n sistematiese wyse pak hy, hoofstuk na hoofstuk, hierdie voorgestelde homiletiese derde weg in helder konsepte uit. Sy invalshoek is 'n pneumatologiese verankerdheid in Jesus Christus, die middelaar van die nuwe verbond. Op die oppervlak van die homiletiese proses is 'n kommunikatiewe driehoeksverhouding, naamlik die teks, die hoorders en die prediker. Die gevaar bestaan egter dat Pneumatologie in die kategorie van menslike ervaring en kompetensie ingetrek kan word. In die dieptevlak van hierdie proses kan ankers ook gevind word in Jesus Christus, die middelaar van die nuwe verbond. In die integratiewe verbondsruimte (met Christus in die sentrum daarvan) verbind die Gees die teks, die hoorders en die prediker op 'n hegte manier aan mekaar op 'n wyse waarin God se bedoeling met die teks gevind kan word. Meditasie, gestroop van negatiewe persepsies, is die toegang tot hierdie homiletiese proses op die dieptevlak. Op hierdie wyse ontwikkel De Wet sy ruimtelike model vir die inkleding van die homiletiese proses in hoofstukke 2 en 3. In hoofstuk 4 ontwikkel die outeur homiletiese instrumente met die oog op die praksis van preekvoorbereiding sodat die verhouding tusssen die teks, die hoorders en die prediker op die dieptevlak vergestalting kan vind. In meditatiewe waarneming speel gebed en die oop gemoed vir God se Woord 'n rol, asook die gebruik van die volle spektrum van taal (intensionele spraakhandeling en relasionele spraakhandeling) en elemente van die retoriese styl waarin die aard van die evangelie onbevange tot sy reg kan kom.

In die lig van die ontwikkelings wat in die afgelope 50 jaar in die Homiletiek plaasgevind het, is 'n boek soos hierdie 'n absolute noodsaaklikheid vir elkeen wat prediking doseer, studeer en beoefen. Hierdie boek voorsien in 'n leemte, naamlik dat daar nou in Afrikaans vir ons kerke, kollegas en studente 'n gereformeerde posisionering kom binne die nuwere ontwikkelings in die Homiletiek. Die boek gee rigting aan elkeen wat die Woord van God helder binne die konteks en leefwêreld van die huidige gemeente wil preek. Prof. De Wet voorsien 'n eie, oorspronklike teorie en praktyk vir die voorbereiding en prediking van die Skrif. Hierdie teorie is binne die nuwe ontwikkelings in die vak ontwerp, sonder die eensydighede wat dikwels hiervan kenmerkend is; boonop is dit gedoen vanuit die bronne van die reformatories-teologiese vertrekpunte.

Die boek word sterk aanbeveel vir dosente, teologiese studente en predikante wat 'n behoefte het aan 'n eietydse en diepgaande siening oor die voorbereiding en prediking van die Skrif in ons huidige konteks.

Die werk vertrek vanuit die vooronderstellings van die reformatoriese teologie. Die invalshoek, die oog of lens waarmee na die prediking gekyk word, is skriftuurlik binne die gereformeerde verstaan van die Skrif. Dit neem deeglik kennis van al die nuwere ontwikkelings in die Homiletiek en met ' $n$ grondige kennis van die literatuur gee dit rigting vir werklik eietydse en aktuele prediking van Jesus Christus in ons konteks. Die boek is nie 'n herhaling van ou standpunte nie, maar verskaf 'n nuwe, vars blik op teologiese vertrekpunte, waarin verrassende insigte vir eietydse gereformeerde prediking oopgemaak word.

Copyright: @ 2013. The Authors. Licensee: AOSIS OpenJournals. This work is licensed under the Creative Commons Attribution License. 